\title{
Increase in Neisseria meningitidis serogroup W invasive disease in Canada: 2009-2016
}

\author{
RSW Tsang ${ }^{1 *}$, L Hoang ${ }^{2}$, GJ Tyrrell ${ }^{3}$, G Horsman ${ }^{4}$, P Van Caeseele $^{5}$, F Jamieson ${ }^{6,7}$, B Lefebvre ${ }^{8}$, \\ D Haldane ${ }^{9,10}$, RR Gad ${ }^{11}$, GJ German ${ }^{12}$, G Zahariadis ${ }^{13,14}$
}

\section{Abstract}

Background: Since 2010, there has been an increase in serogroup W Neisseria meningitidis (MenW) disease in many countries due to an emerging sequence type-11 clonal complex (ST-11 CC). In 2016, a small increase in MenW disease due to the ST-11 CC was documented in Ontario, Canada.

Objective: To examine the trends in MenW disease in Canada and to assess whether there have been changes in the type of ST clonal complex causing MenW disease between 2009-2016.

Methods: Invasive N. meningitidis isolates routinely submitted from across the country to the National Microbiology Laboratory were analyzed. The proportional distribution of MenW compared with other serogroups was calculated. The MenW isolates were then further characterized by serotype, serosubtype and ST clonal complex. The geographic distribution of the emerging ST-11 CC was documented and the age of patients with ST-11 CC was compared with the traditional ST-22 CC.

Results: Of the 888 invasive isolates examined, 63 were MenW giving an average annual rate of $7.1 \%$. However, the percentage of MenW varied from $2.7 \%$ in 2012 to $18.8 \%$ in 2016 . From 2009 to $2013,91 \%$ of the MenW were typed as the traditional ST-22 CC while from 2014 to 2016, 75\% were typed to be the emerging ST-11 CC. ST-11 MenW CC was documented in five provinces across Canada (British Columbia, Alberta, Manitoba, Ontario and Quebec). The median age of patients infected with the emerging ST-11 MenW CC was 53.5 years, while for patients with the traditional ST-22 CC it was 23.5 years.

Conclusion: MenW meningococcal disease is growing in prevalence in Canada and is associated with an increase in the emerging ST-11 CC. This emerging clonal complex has now been identified in five provinces in Canada. It appears to be more common in older patients than the traditional ST-22 CC, which occurs more often in younger patients.

Suggested citation: Tsang RSW, Hoang L, Tyrrell GJ, Horsman G, Van Caeseele P, Jamieson F, Lefebvre B, Haldane D, Gad RR, German GJ, Zahariadis G. Increase in Neisseria meningitidis serogroup W invasive disease in Canada: 2009-2016. Can Commun Dis Rep. 2017;43(7/8):144-9. https://doi.org/10.14745/ccdr.v43i78a01

\author{
Affiliations \\ ${ }^{1}$ National Microbiology \\ Laboratory, Public Health Agency \\ of Canada, Winnipeg, MB \\ ${ }^{2}$ BC Public Health Microbiology \\ and Reference Laboratory, \\ Vancouver, BC \\ 3 Provincial Laboratory for Public \\ Health, Edmonton, AB \\ ${ }^{4}$ Saskatchewan Disease Control \\ Laboratory, Regina, SK \\ ${ }^{5}$ Cadham Provincial Laboratory, \\ Winnipeg, MB \\ ${ }^{6}$ Public Health Ontario, Toronto, \\ ON \\ ${ }^{7}$ Faculty of Medicine, University \\ of Toronto, Toronto, ON \\ ${ }^{8}$ Laboratoire de santé publique \\ du Québec, Institut national \\ de santé publique du Québec, \\ Sainte-Anne-de-Bellevue, QC \\ ${ }^{9}$ Nova Scotia Health Authority, \\ Halifax, NS \\ ${ }^{10}$ Dalhousie University, Halifax, \\ NS \\ ${ }^{11}$ Communicable Disease Control \\ Unit, Department of Health, \\ Government of New Brunswick, \\ Fredericton, NB \\ ${ }^{12}$ Department of Health, \\ Government of Prince Edward \\ Island, Charlottetown, PE \\ ${ }^{13}$ Provincial Public Health \\ Laboratory, Eastern Health \\ Microbiology Services, St. John's, \\ $\mathrm{NL}$ \\ ${ }^{14}$ Department of Laboratory \\ Medicine, Faculty of Medicine, \\ Memorial University of \\ Newfoundland, St. John's, NL
}

Correspondence: raymond. tsang@phac-aspc.gc.ca

\section{Introduction}

Invasive meningococcal disease (IMD) has been a notifiable disease in Canada since 1924 (1). It is caused by Neisseria meningitidis, which normally resides in the upper respiratory tract of healthy carriers. For reasons not completely understood, N. meningitidis may invade the blood stream and cause serious systemic infection leading to meningitis, septicemia, septic arthritis, bacteremic pneumonia and pericarditis (2). Initial clinical presentation of IMD can be nonspecific but it may progress rapidly, leading to septic shock. The disease has an average case-fatality rate of $10 \%(3)$.

N. meningitidis is classified into 12 serogroups based on antigenic specificities of their polysaccharide capsules. Most invasive diseases are caused by six serogroups: $A(M e n A)$, B (MenB), C (MenC), W (MenW), X (MenX) and Y (MenY). 
These invasive strains belong to a handful of genetic lineages known as hypervirulent clones, such as sequence type (ST)-32 [electrophoretic type (ET)-5], ST-41/44 (lineage 3), ST-11 (ET-37), ST-8 (cluster A4), ST-5 (subgroup III) and ST-269 clonal complexes (CCs) $(4,5)$.

The strains causing IMD have been described as "shifting sands", with unique strains emerging with the potential to spread regionally and internationally. For example, MenA of subgroup III caused epidemics in China in the 1960s and subsequently spread to Russia and then globally (6). ET-5 MenB caused an intercontinental outbreak with a wide geographic spread that lasted for over a decade (7). The ET-15 MenC clone first emerged in Canada in the mid-1980s and led to worldwide dissemination, which ultimately led to the introduction of MenC conjugate vaccine programs in many countries. Other notable MenB clones that have caused epidemics include cluster A4 and lineage 3 (5).

The first report of MenW causing a major outbreak or epidemic occurred in 2000; this outbreak started in Saudi Arabia during the Hajj and involved more than 400 cases. The strain was characterized as ST-11 clonal complex (8). With pilgrims returning to their countries in Africa, Asia, Europe, North America and South America, this strain was disseminated globally. The gradual increase in MenW disease in recent years was first reported in sub-Saharan Africa (9) and South America $(10,11)$. Since 2010, other countries have reported an increase in IMD caused by ST-11 MenW (12-15).

In December 2016, Tsang et al. (16) reported an increase in invasive MenW strains in Ontario, Canada. This increase started in 2014 and was associated with a replacement of the traditional ST-22 clonal complex with the ST-11 clonal complex (16). There was also a small increase in the number of MenW IMD cases in that province. To determine if clonal replacement had occurred in MenW disease nationally, this study examines the trends in MenW disease and changes in clonal complex in Canada between 2009 and 2016.

\section{Methods}

Provincial public health laboratories receive case isolates from hospitals and clinical diagnostic laboratories for identification and serogroup typing. As part of the enhanced surveillance program on IMD, all provinces and territories in Canada routinely submit all their invasive $N$. meningitidis isolates from culture-confirmed cases to the National Microbiology Laboratory (NML) for serogroup confirmation and additional strain characterization (17). This study included all N. meningitidis isolates obtained from culture-confirmed IMD cases submitted to the NML between 2009 and 2016.

\section{Typing of meningococci}

At the NML, serogrouping is done by slide agglutination using rabbit anti-grouping antisera produced in-house and/or polymerase chain reaction (PCR) (18). Serotyping and serosubtyping is done by whole-cell enzyme-linked immunosorbent assay (ELISA) using monoclonal antibodies (19). PorA genotyping and multilocus sequence typing were conducted according to previously described standard methods $(20,21)$.

\section{Geographic distribution, source and patient characteristics}

Based on the requisition information provided by the provincial public health laboratories, the NML collects and analyzes information on the geographic origin of the specimens, the source (e.g. blood, cerebral spinal, pericardial or intra-articular fluid) and the age and sex of patients from whom the specimens were drawn.

\section{Results}

\section{Trends in MenW meningococcal disease}

In Canada, between 2009 and 2016, a total of 888 N. meningitidis isolates were recovered from individual IMD cases and sent to the NML. Of these, 63 were grouped as MenW. The percentage of MenW isolates varied by year from a low of $2.7 \%$ in 2012 to a high of $18.8 \%$ in 2016 (Table 1), for an average percentage of $7.1 \%$.

Table 1: Contribution of Neisseria meningitidis serogroup W (MenW) in culture-positive invasive meningococcal disease cases, Canada 2009-2016

\begin{tabular}{|c|r|r|r|}
\hline Year & $\begin{array}{c}\text { Number of } \\
\text { MenW case } \\
\text { isolates }\end{array}$ & $\begin{array}{c}\text { Total number } \\
\text { of IMD case } \\
\text { isolates }\end{array}$ & $\begin{array}{c}\text { MenW case } \\
\text { isolates as a } \\
\text { percentage } \\
\text { of IMD case } \\
\text { isolates }\end{array}$ \\
\hline 2009 & 12 & 168 & $7.1 \%$ \\
\hline 2010 & 6 & 118 & $5.1 \%$ \\
\hline 2011 & 10 & 133 & $7.5 \%$ \\
\hline 2012 & 3 & 112 & $2.7 \%$ \\
\hline 2013 & 5 & 103 & $4.9 \%$ \\
\hline 2014 & 6 & 86 & $7.0 \%$ \\
\hline 2015 & 6 & 88 & $6.8 \%$ \\
\hline 2016 & 15 & 80 & $18.8 \%$ \\
\hline All years & 63 & 888 & $7.1 \%$ \\
\hline Abbreviations: IMD, invasive meningococcal disease; MenW, Neisseria meningitidis serogroup W
\end{tabular}

\section{Changes in clonal complex}

The increase in the number of MenW isolates from IMD cases coincided with the identification of the ST-11 (ET-37) CC

(Figure 1). From 2009 to 2013, 91\% (32 out of 35) MenW isolates were typed as the traditional ST-22 clonal complexes whereas from 2014 to 2016, only 25\% (7 out of 28) MenW isolates belonged to this clonal complex. Over this same period, the emerging ST-11 clonal complex increased from 3\% (1 out of 35 isolates) to $75 \%$ (21 out of 28 isolates).

\section{Antigenic and genetic characterization}

Almost 70\% (27 out of 39) of the traditional ST-22 CC MenW isolates were typed as either W:NT (non-serotypeable):P1.6 $(n=19)$ or W:NT:P1.- (non-serosubtypeable; $n=8$ ) with the PorA genotype of P1.18-1,3,38. Five other ST-22 MenW were 
Figure 1: Clonal analysis of invasive Neisseria meningitidis serogroup W (MenW) in Canada, 2009-2016

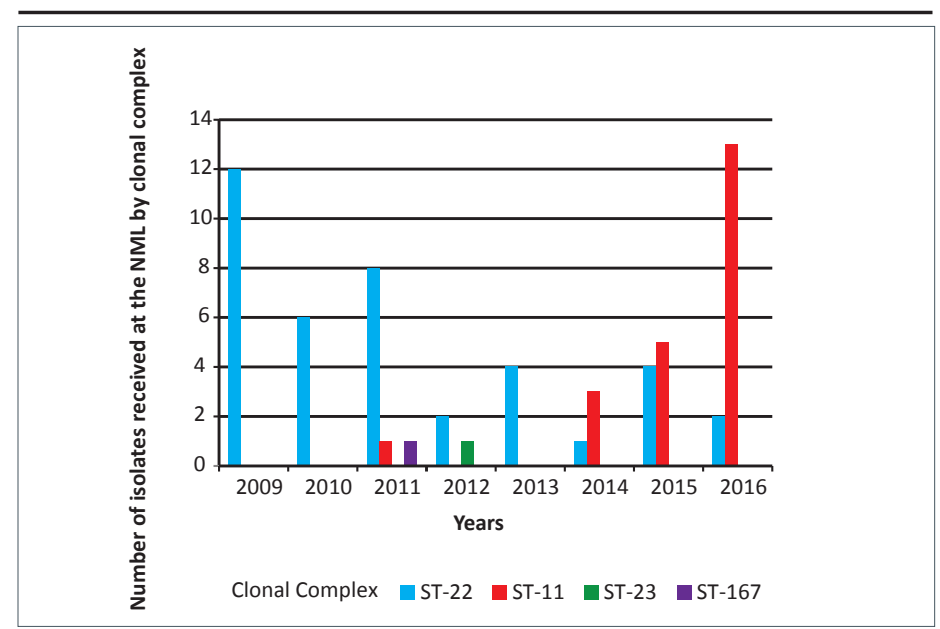

Abbreviations: NML, National Microbiology Laboratory; ST, sequence type

typed as W:NT:P1.- with a deletion in their PorA genes. The other seven ST-22 CC MenW were non-serotypeable with serosubtype antigens of either P1.5 $(n=1), P 1.5,2(n=1), P 1.14$ $(n=2)$, P1.16 $(n=2)$ or P1.- $(n=1)$. Twelve different sequence types were identified among these 39 ST-22 CC MenW, with 15 isolates belonging to ST-184, 11 to ST-22, three to ST-8974 and two to ST-1617. The remaining eight isolates each belonged to a different sequence type (ST-1221, ST-1224, ST-1476, ST-2625, ST-3137, ST-3849, ST-8230 and ST-10188).

In contrast, $100 \%$ (all 22) of the ST-11 CC MenW isolates were typed as C:2a:P1.5,2 (n=21) or C:2a:P1.2 $(n=1)$, with the PorA genotype of P1.5,2,36-2. Twenty-one belonged to ST-11 and one to ST-10826. There was also one MenW isolate that typed as ST-23 (ST-23 CC) and one isolate typed as ST-3705 (ST-167 CC). The former had the antigenic formula of W:19:P1.- with PorA genotype of $\mathrm{P} 1.5-2,10-1,36-2$ while the later was $\mathrm{W}: 19: P 1.5$ with PorA genotype of P1.5-1,10-4,36-2.

\section{Geographic, demographic and source data}

MenW isolates of the ST-11 CC were found in British Columbia $(n=5)$, Alberta $(n=3)$, Manitoba $(n=2)$, Ontario $(n=8)$ and Quebec $(n=4)$. The sex and age distribution of cases due to ST-22 and ST-11 CCs are shown in Table 2. For the traditional ST-22 CC MenW cases, the mean and median ages were 31.7 years and 23.5 years, respectively. The mean and median ages of patients with emerging ST-11 CC MenW were 47.9 years and 53.5 years, respectively. Eight patients under 2 years old were identified with ST-22 CC MenW; no one in this age group was diagnosed with ST-11 CC MenW. Of the ST-22 CC MenW isolates, 33 were from blood cultures, three from cerebral spinal fluid cultures, two from articular fluids and one from the pericardial fluid. Of the 22 isolates of ST-11 CC MenW from across Canada, 21 were from blood cultures and only one from cerebral spinal fluid culture.
Table 2: Demographic characteristics and specimen source for invasive Neisseria meningitidis serogroup W (MenW) cases according to clonal complex in Canada, 2009-2016

\begin{tabular}{|c|c|c|}
\hline $\begin{array}{c}\text { Demographics } \\
\text { and specimen } \\
\text { source }\end{array}$ & $\begin{array}{c}\text { ST-22 clonal } \\
\text { complex isolates } \\
n(\%)\end{array}$ & $\begin{array}{c}\text { ST-11 clonal } \\
\text { complex isolates } \\
n(\%)\end{array}$ \\
\hline \multicolumn{3}{|c|}{ Sex } \\
\hline Male & 20 (51\%) & 13 (59\%) \\
\hline Female & $19(49 \%)$ & 9 (41\%) \\
\hline \multicolumn{3}{|c|}{ Age } \\
\hline$<12$ months & $4(10 \%)$ & 0 \\
\hline $12-23$ months & $4(10 \%)$ & 0 \\
\hline $2-5$ years & $6(15 \%)$ & $2(10 \%)$ \\
\hline $6-10$ years & $1(3 \%)$ & 0 \\
\hline $11-20$ years & $5(13 \%)$ & $4(18 \%)$ \\
\hline $21-40$ years & 5 (13\%) & $2(10 \%)$ \\
\hline $41-60$ years & 5 (13\%) & 7 (31\%) \\
\hline$>60$ years & 8 (21\%) & 7 (31\%) \\
\hline Unknown & $1(3 \%)$ & 0 \\
\hline \multicolumn{3}{|c|}{ Specimen source } \\
\hline Blood & 33 (84.6\%) & $21(95 \%)$ \\
\hline $\begin{array}{l}\text { Cerebral spinal } \\
\text { fluid }\end{array}$ & $3(7.7 \%)$ & $1(5 \%)$ \\
\hline Others ${ }^{1}$ & $3(7.7 \%)$ & 0 \\
\hline $\begin{array}{l}\text { Total number. of } \\
\text { samples }\end{array}$ & $39(100 \%)$ & 22 (100\%) \\
\hline
\end{tabular}

Abbreviations: $n$, number; $S T$, sequence type

'Shoulder, pericardial or articular fluid

\section{Discussion}

From 2009 to 2016, while the overall number of IMD cases in Canada decreased, the percentage of cases due to MenW increased from $2.7 \%$ in 2012 to $18.8 \%$ in 2016 . This increase in MenW disease was associated with a clonal shift in the MenW strain from ST-22 CC to ST-11 CC. This emerging ST-11 CC MenW clone has now been documented in five provinces. It tends to occur in middle-aged and older adults.

ST-11 CC is a long-established hypervirulent clonal complex that was first identified in 1917 in a serogroup B strain (5). In the 1960s and 1970s, ST-11 CC was associated with MenB in North America and Europe (5). In the mid-1980s, a genetic variant of ST-11 CC that caused IMD in teenagers in Ontario appeared in a MenC clone designated as ET-15 (22). Like others in the ST-11 clonal complex, this ET-15 clone spread rapidly in North America and eventually globally (23). The MenC conjugate vaccine was first included in the publically funded childhood immunization program in the United Kingdom, in 1999 (24). In Canada, the MenC conjugate vaccine was licensed in April 2001. Beginning in 2002, some provinces started routine MenC conjugate vaccine immunisation programs and by 2007 all provinces and territories have implemented such programs (25). 
The first major ST-11 CC MenW outbreak occurred during the Hajj pilgrimage in 2000. The pilgrims returning to their countries initiated the global dissemination of this clone (26). In England and Wales, the increase in the ST-11 MenW clone first became apparent in 2009/2010 (27) and its prevalence increased yearly until 2015 when a targeted vaccination program was introduced (28). A similar increase in MenW disease as a result of the same clone has been seen in Australia since 2013 (29), also leading to the introduction of a targeted vaccination program (30). The ST-11 CC MenW has now been documented in a number of other countries around the world (9-15).

The Canadian ST-11 CC MenW isolates have serotype antigen 2a and serosubtype antigen P1.5,2, typical of isolates of this clonal complex (31). They also differ antigenically from meningococci of the ST-22 CC. Currently there is no evidence to suggest that these ST-11 MenW arose by capsule switching from MenC ST-11 strain. Investigations into the MenB ST-11 that arose from MenC ST-11 by capsule switching suggest that these capsule-switched strains may not be stable for endemic spread (32). Rather, the increase in MenW ST-11 isolates in Canada and elsewhere is likely due to clonal expansion of an endemic strain $(25,26)$.

This study has two limitations. First, it included only bacteriologic culture-confirmed cases and not those confirmed using PCR. However, only about $10 \%$ of the IMD cases confirmed in Canada between 2006 and 2011 were diagnosed by PCR (17) and there is no evidence to suggest that PCR-diagnosed cases differ from culture-confirmed cases. Second, this study does not include data on the meningococcal vaccination history of patients with MenW. The quadrivalent meningococcal $A, C, W$ and $Y$ conjugate vaccine has protective immunity against MenW, but determining if any of the patients had been vaccinated prior to their illness was not possible.

Some provinces in Canada have quadrivalent meningococcal A, $C, W$ and $Y$ conjugate vaccine programs targeting primary or high school students (33). The protective immunity offered by this quadrivalent vaccine in the student population may have moderated the effect of the expansion of the ST-11 MenW clone in Canada. Of note, fewer MenW cases have been identified in Canada than in the United Kingdom or Australia, where a vaccine program was more recently introduced $(28,30)$.

It is important to note that IMD due to MenW ST-11 CC may have an atypical clinical presentation. In England, for example, a review of MenW cases in teenagers (aged 15 to 19 years) found that 7 out of 15 patients initially presented with acute gastrointestinal symptoms of nausea, vomiting and diarrhea; four were sent home from hospital, delaying the diagnosis (34). In another study of $129 \mathrm{MenW}$ cases in England and Wales from 2010 to 2013 , half of which were diagnosed in patients aged 45 years or above, $23 \%$ were with atypical clinical presentations of pneumonia (12\%), septic arthritis (7\%) and epiglottitis or supraglottitis (4\%) (26). The unusual initial clinical symptoms may have implications in the early diagnosis of the disease. Timely diagnosis of IMD is important for patient treatment, contact tracing and public health control of the disease. Ongoing surveillance of these trends is indicated.

\section{Conclusion}

In summary, the traditional endemic MenW ST-22 CC has been replaced by an abrupt emergence of MenW ST-11 CC in five provinces in Canada. Although the overall number of MenW cases in Canada remains small, MenW is responsible for $19 \%$ of all IMD cases. Of note for clinicians and public health professionals, this ST-11 MenW clone has the potential to cause outbreaks, has occurred in an older age group in Canada and may have an atypical clinical presentation. The NML will continue its surveillance program on this disease including laboratory characterization of strains.

\section{Authors' statement}

All authors (RSWT, LH, GJT, GH, PVC, FJ, BL, DH, RRG, GJG, and $\mathrm{GZ}$ ) are involved in the surveillance of invasive meningococcal disease in Canada. RSWT prepared the first draft and all authors contributed to the final version with comments and suggestions.

\section{Conflict of interest}

None.

\section{Acknowledgements}

We thank the staff at the provincial public health laboratories for identifying and sending $N$. meningitidis isolates to the NML. We also thank Dennis Law, Jianwei Zhou, and Saul Deng for providing laboratory assistance in the analysis of strains, and the NML's DNA Core Service for providing assistance in nucleotide sequencing. The authors made use of the Neisseria Multi Locus Sequence Typing website (https://pubmlst.org/neisseria/) developed by Keith Jolley and sited at the University of Oxford (BMC Bioinformatics at https://bmcbioinformatics.biomedcentral. com/articles/10.1186/1471-2105-11-595). The development of this site was funded by the Wellcome Trust and the European Union.

\section{Funding}

Laboratory surveillance of invasive meningococcal disease is funded by the Public Health Agency of Canada.

\section{References}

1. Varughese PV, Cartr AO. Meningococcal disease in Canada, surveillance summary to 1987. Can Dis Wkly Rep. 1989;15(17):8996. PubMed: https://www.ncbi.nlm.nih.gov/entrez/query.fcgi?cmd= Retrieve \&db=PubMed\&list_uids=2720807\&dopt=Abstract.

2. Apicella MA. Neisseria meningitidis. In: Mandell G, Bennett JE, Dolin R, editors. Mandell, Douglas, and Bennett's principles and practice of infectious diseases, 7th edition, Philadelphia (PA): Churchill Livingstone Elsevier; 2009. p. 2737-52.

3. Rosenstein NE, Perkins BA, Stephens DS, Popovic T, Hughes JM. Meningococcal disease. N Engl J Med. 2001;344(18):1378-88. 
DOI: http://dx.doi.org/10.1056/NEJM200105033441807. PubMed (https://www.ncbi.nlm.nih.gov/entrez/query.fcgi?cmd=Retrieve\&db $=$ PubMed\&list_uids=11333996\&dopt=Abstract).

4. Harrison LH, Trotter CL, Ramsay ME. Global epidemiology of meningococcal disease. Vaccine. 2009;27(Suppl 2):B51-63. DOI: http://dx.doi.org/10.1016/j.vaccine.2009.04.063. PubMed (https:// www.ncbi.nlm.nih.gov/entrez/query.fcgi?cmd=Retrieve\&db=PubM ed\&list_uids=19477562\&dopt=Abstract).

5. Caugant DA. Population genetics and molecular epidemiology of Neisseria meningitidis. APMIS. 1998;106(5):505-25. DOI: http:// dx.doi.org/10.1111/j.1699-0463.1998.tb01379.x. PubMed (https:// www.ncbi.nlm.nih.gov/entrez/query.fcgi?cmd=Retrieve\&db=PubM ed\&list_uids=9674888\&dopt=Abstract).

6. Olyhoek T, Crowe BA, Achtman M. Clonal population structure of Neisseria meningitidis serogroup $A$ isolated from epidemics and pandemics between 1915 and 1983. Rev Infect Dis. 1987;9:665-92. DOI: http://dx.doi.org/10.1093/clinids/9.4.665. PubMed (https:// www.ncbi.nlm.nih.gov/entrez/query.fcgi?ccmd=Retrieve\&db=PubM ed\&list_uids=3125576\&dopt=Abstract).

7. Caugant DA, Froholm LO, Bovre K, Holten E, Frasch CE, Mocca LF, Zollinger WD, Selander RK. Intercontinental spread of a genetically distinct complex of clones of Neisseria meningitidis causing epidemic disease. Proc Natl Acad Sci USA. 1986;83(13):4927-31. DOI: http://dx.doi.org/10.1073/pnas.83.13.4927. PubMed (https:// www.ncbi.nlm.nih.gov/entrez/query.fcgi?cmd=Retrieve\&db=PubM ed\&list_uids=3088568\&dopt=Abstract).

8. Taha MK, Achtman M, Alonso JM, Greenwood B, Ramsay M, Fox A, Gray S, Kaczmarski E. Serogroup W135 meningococcal disease in Hajj pilgrims. Lancet. 2000 Dec;356(9248):2159. DOI: http://dx.doi. org/10.1016/S0140-6736(00)03502-9. PubMed (https://www.ncbi. $\mathrm{nlm}$.nih.gov/entrez/query.fcgi?cmd=Retrieve\&db=PubMed\&lis t_uids $=11191548 \&$ dopt $=$ Abstract).

9. Parent du Châtelet I, Traore Y, Gessner BD, Antignac A, Naccro B, Njanpop-Lafourcade BM, Ouedraogo MS, Tiendrebeogo SR, Varon E, Taha MK. Bacterial meningitis in Burkina Faso: surveillance using field-based polymerase chain reaction testing. Clin Infect Dis. 2005 Jan;40(1):17-25. DOI: http://dx.doi.org/10.1086/426436. PubMed (https://www.ncbi.nlm.nih.gov/entrez/query.fcgi?cmd=Retrieve\&db $=$ PubMed\&list_uids=15614687\&dopt=Abstract).

10. Weidlich L, Baethgen LF, Mayer LW, Moraes C, Klein CC, Nunes LS, Rios S da S, Kmetzsch Cl, Rossetti ML, Zaha A. High prevalence of Neisseria meningitidis hypervirulent lineages and emergence of W135:P1.5,2:ST-11 clone in Southern Brazil. J Infect. 2008;57:32431. DOI: http://dx.doi.org/10.1016/j.jinf.2008.07.014. PubMed (https://www.ncbi.nlm.nih.gov/entrez/query.fcgi?cmd=Retrieve\&db $=$ PubMed\&list_uids=18814914\&dopt=Abstract).

11. Efron AM, Sorhouet $C$, Salcedo C, Abad R, Regueira M, Vazquez JA. W135 invasive meningococcal strains spreading in South America: significant increase in incidence rate in Argentina. J Clin Microbiol. 2009 Jun;47(6):1979-80. DOI: http://dx.doi. org/10.1128/JCM.02390-08. PubMed (https://www.ncbi.nlm. nih.gov/entrez/query.fcgi?cmd=Retrieve\&db=PubMed\&list_ uids $=19357205 \&$ dopt=Abstract).

12. Collard JM, Maman Z, Yacouba H, Djibo S, Nicolas P, Jusot, JF, Rocourt J, Maitournam R. Increase in Neisseria meningitidis serogroup W135, Niger, 2012 Letter to: Emerg Infect Dis. 2010 Sep; 16(9):1496-8. DOI: http://dx.doi.org/10.3201/eid1609.100510. PubMed (https://www.ncbi.nlm.nih.gov/entrez/query.fcgi?cmd=Ret rieve\&db=PubMed\&list_uids=20735947\&dopt=Abstract).

13. Hossain MJ, Roca A, Mackenzie GA, Jasseh M, Hossain MI, Muhammad S, Ahmed M, Chidiebere OD, Malick N, Bilquees SM, Ikumapayi UN, Jeng B, Njie B, Cham M, Kampmann B, Corrah T, Howie S, D'Alessandro U. Serogroup W135 meningococcal disease, The Gambia, 2012. Emerg Infect Dis. 2013 Sep;19(9):1507-10. DOI: http://dx.doi.org/10.3201/eid1909.130077. PubMed (https://www. ncbi.nlm.nih.gov/entrez/query.fcgi?cmd=Retrieve\&db=PubMed\&li st_uids $=23965435 \&$ dopt $=$ Abstract $)$.
14. Zhou H, Liu W, Xu L, Deng L, Deng Q, Zhuo J, Shao Z. Spread of Neisseria meningitidis serogroup W clone, China. Emerg Infect Dis. 2013 Sep;19(9):1496-9. DOI: http://dx.doi. org/10.3201/eid1909.130160. PubMed (https://www.ncbi.nlm. nih.gov/entrez/query.fcgi?cmd=Retrieve\&db=PubMed\&list_ uids=23965378\&dopt=Abstract).

15. Hu S, Zhang W, Li F, Hu Z, Ma E, Zheng T, Zhao Y, Li W, Zhou H, Shao Z, Xu J. Neisseria meningitidis serogroup W135 sequence type 11, Anhui Province, China, 2011-2013. Emerg Infect Dis. 2014 Jul;20(7):1236-8. DOI: http://dx.doi.org/10.3201/eid2007.131138. PubMed (https://www.ncbi.nlm.nih.gov/entrez/query.fcgi?cmd=Ret rieve\&db=PubMed\&list_uids=24960586\&dopt=Abstract).

16. Tsang RSW, Deeks SL, Wong K, Marchand-Austin A, Jamieson FB. Invasive serogroup W Neisseria meningitides (MenW) in Ontario, Canada shows potential clonal replacement during the period January 1, 2009 to June 30, 2016. Can Commun Dis Rep. 2016;42(12):263-6. Available from: http://www.phac-aspc.gc.ca/ publicat/ccdr-rmtc/16vol42/dr-rm42-12/ar-06-eng.php.

17. Li YA, Tsang R, Desai S, Deehan H. Enhanced surveillance of invasive meningococcal disease in Canada, 2006-2011. Can Commun Dis Rep. 2014 40(9):160-9. Available from: http://www. phac-aspc.gc.ca/publicat/ccdr-rmtc/14vol40/dr-rm40-09/dr-rm4009-surv-eng.php.

18. Tsang R, Taha MK. Diagnosis of meningococcal disease. In: Feavers I, Pollard AJ, Sadaranghi M, editors. Handbook of meningococcal disease management. Cham (CH) Springer International Publishing Switzerland; 2016. p. 45-55.

19. Abdillahi $H$, Poolman JT. Whole cell ELISA for typing Neisseria meningitidis with monoclonal antibodies. FEMS Microbiol Lett. 1987;48:367-71. DOI: http://dx.doi.org/10.1111/j.1574-6968.1987. tb02626.x.

20. Jamieson FB, Rawte P, Deeks SL, Zhou J, Law DK, Deng S, Tsang RS. Genetic and antigenic characterization of invasive endemic serogroup B Neisseria meningitidis in Ontario, Canada, in 20012010 [Internet]. J Med Microbiol. 2013 62(1):46-55. DOI: http:// dx.doi.org/10.1099/jmm.0.050369-0. PubMed (https://www.ncbi. $\mathrm{nlm}$.nih.gov/entrez/query.fcgi?cmd=Retrieve\&db=PubMed\&lis t_uids $=23038803 \&$ dopt $=$ Abstract).

21. Zhou J, Lefebvre B, Deng S, Gilca R, Deceuninck G, Law DK, De Wals P, Tsang RS. Invasive serogroup B Neisseria meningitidis in Quebec, Canada, 2003 to 2010: persistence of the ST-269 clone since it first emerged in $2003 \mathrm{~J}$ Clin Microbiol. 2012 50(5) 1545-51. DOI: http://dx.doi.org/10.1128/JCM.06835-11. PubMed (https:// www.ncbi.nlm.nih.gov/entrez/query.fcgi?cmd=Retrieve\&db=PubM ed\&list_uids=22337990\&dopt=Abstract).

22. Ashton FE, Ryan JA, Borczyk A, Caugant DA, Mancino L, Huang D. Emergence of a virulent clone of Neisseria meningitidis serotype $2 a$ that is associated with meningococcal serogroup $C$ disease in Canada [Internet]. J Clin Microbiol. 1991 29:2489-93. PubMed (https://www.ncbi.nlm.nih.gov/entrez/query.fcgi?cmd=Retrieve\&db =PubMed\&list_uids=1774254\&dopt=Abstract).

23. Jelfs J, Munro R, Ashton FE, Caugant DA. Genetic characterization of a new variant within the ET-37 complex of Neisseria meningitidis associated with outbreaks in various parts of the world [Internet]. Epidemiol Infect. 2000 125:285-98. DOl: http://dx.doi. org/10.1017/S0950268899004471. PubMed (https://www.ncbi. $\mathrm{nlm}$.nih.gov/entrez/query.fcgi?cmd=Retrieve\&db=PubMed\&lis t_uids=11117951\&dopt=Abstract).

24. Miller E, Salisbury D, Ramsay M. Planning, registration, and implementation of an immunisation campaign against meningococcal serogroup $\mathrm{C}$ disease in the UK: a success story. Vaccine. 2001;20(Suppl 1):S58-67. DOI: http://dx.doi. org/10.1016/S0264-410X(01)00299-7. PubMed (https://www.ncbi. $\mathrm{nlm}$.nih.gov/entrez/query.fcgi?cmd=Retrieve\&db=PubMed\&lis t_uids=11587814\&dopt=Abstract).

25. National Advisory Committee on Immunization (NACl). An Advisory Committee Statement (ACS) Update on the invasive meningococcal disease and meningococcal vaccine conjugate recommendations. 
Can Commun Dis Rep 2009; 35(ACS-3):1-40. PubMed (https:// www.ncbi.nlm.nih.gov/entrez/query.fcgi?cmd=Retrieve\&db=PubM ed\&list_uids=19400026\&dopt=Abstract).

26. Mayer LW, Reeves MW, Al-Hamdan N, Sacchi CT, Taha MK, Ajelllo GW, Schmink SE, Noble CA, Tondella ML, Whitney AM, Al-Mazrou Y, Al-Jefri M, Mishkhis A, Sabban S, Caugant DA, Lingappa J, Rosenstein NE, Popovic T. Outbreak of W135 meningococcal disease in 2000: not emergence of a new W135 strain but clonal expansion within the electrophoretic type -37 complex J Infect Dis. 2002 185:1596-605. DOI: http://dx.doi.org/10.1086/340414. PubMed (https://www.ncbi.nlm.nih.gov/entrez/query.fcgi?cmd=Ret rieve \&db=PubMed\&list_uids=12023765\&dopt=Abstract).

27. Ladhani SN, Beebeejaun K, Lucidarme J, Campbell H, Gray S, Kaczmarski E, Ramsay ME, Borrow R. Increase in endemic Neisseria meningitidis capsular group W sequence type 11 complex associated with severe invasive disease in England and Wales Clin Infect Dis. 2015;60:578-85

28. Campbell H, Saliba V, Borrow R, Ramsay R, Ladhani SN. Targeted vaccination of teenagers following continued rapid endemic expansion of a single meningococcal group W clone (sequence type 11 clonal complex), United Kingdom, 2015. Euro Surveill. 2015;20(28): pii=21188. DOI: http://dx.doi.org/10.2807/15607917.ES2015.20.28.21188. PubMed (https://www.ncbi.nlm. nih.gov/entrez/query.fcgi?cmd=Retrieve $\& \mathrm{db}=$ PubMed\&lis t_uids=26212140\&dopt=Abstract).

29. Martin NV, Ong KS, Howden BP, Lahra MM, Lambert SB, Beard FH, Dowse GK, Saul N; Communicable Diseases Network Australia MenW Working Group. Rise in serogroup W meningococcal disease in Australia 2013-2015. Commun Dis Intell Q Rep. 2016;40(4):E4549. PubMed (https://www.ncbi.nlm.nih.gov/entrez/query.fcgi?cmd= Retrieve\&db=PubMed\&list_uids=28043219\&dopt=Abstract)
30. Government of Western Australia. Media Statement. Targeted campaign against meningococcal W [Internet]. 2016 Dec 8 [cited 2017 May 1]. Available from: https://www.mediastatements. wa.gov.au/Pages/Barnett/2016/12/Targeted-campaign-againstmeningococcal-W.aspx.

31. Wang JF, Caugant DA, Morelli G, Koumaré B, Achtman M. Antigenic and epidemiologic properties of the ET-37 Neissera meningitidis. J Infect Dis. 1993;167:1320-9. DOI: http://dx.doi. org/10.1093/infdis/167.6.1320. PubMed (https://www.ncbi. $\mathrm{nlm}$.nih.gov/entrez/query.fcgi? $\mathrm{cmd}=$ Retrieve \&db=PubMed\&lis t_uids $=8501321 \&$ dopt $=$ Abstract).

32. Tyler $\mathrm{S}$, Tsang R. Genetic analysis of Canadian isolates of C:2a:P1.2,5 and B:2a:P1.2,5 Neisseria meningitidis strains belonging to the hypervirulent clone of ET-15. Can J Microbiol. 2004;50 433-43. PubMed (https://www.ncbi.nlm. nih.gov/entrez/query.fcgi?cmd=Retrieve\&db=PubMed\&list_ uids $=15284889 \&$ dopt=Abstract).

33. Public Health Agency of Canada. Canada's provincial and territorial routine (and catch-up) vaccination programs for infants and children [Internet]. Ottawa (ON): Government of Canada; [modified: 2017 Apr 3; cited 2017 May 1]. Available from: https://www.canada. $\mathrm{ca} /$ en/public-health/services/provincial-territorial-immunizationinformation/provincial-territorial-routine-vaccination-programsinfants-children.html.

34. Campbell H, Parikh SR, Borrow R, Kaczmarski E, Ramsay ME, Ladhani SN. Presentation with gastrointestinal symptoms and high case fatality associated with group $\mathrm{W}$ meningococcal disease (MenW) in teenagers, England, July 2015 to January 2016 [Internet]. Euro Surveill. 2016;21(12): pii = 30175. DOI: http:// dx.doi.org/10.2807/1560-7917.ES.2016.21.12.30175. PubMed (https://www.ncbi.nlm.nih.gov/entrez/query.fcgi?cmd=Retrieve\&db $=$ PubMed\&list_uids=27035055\&dopt=Abstract).

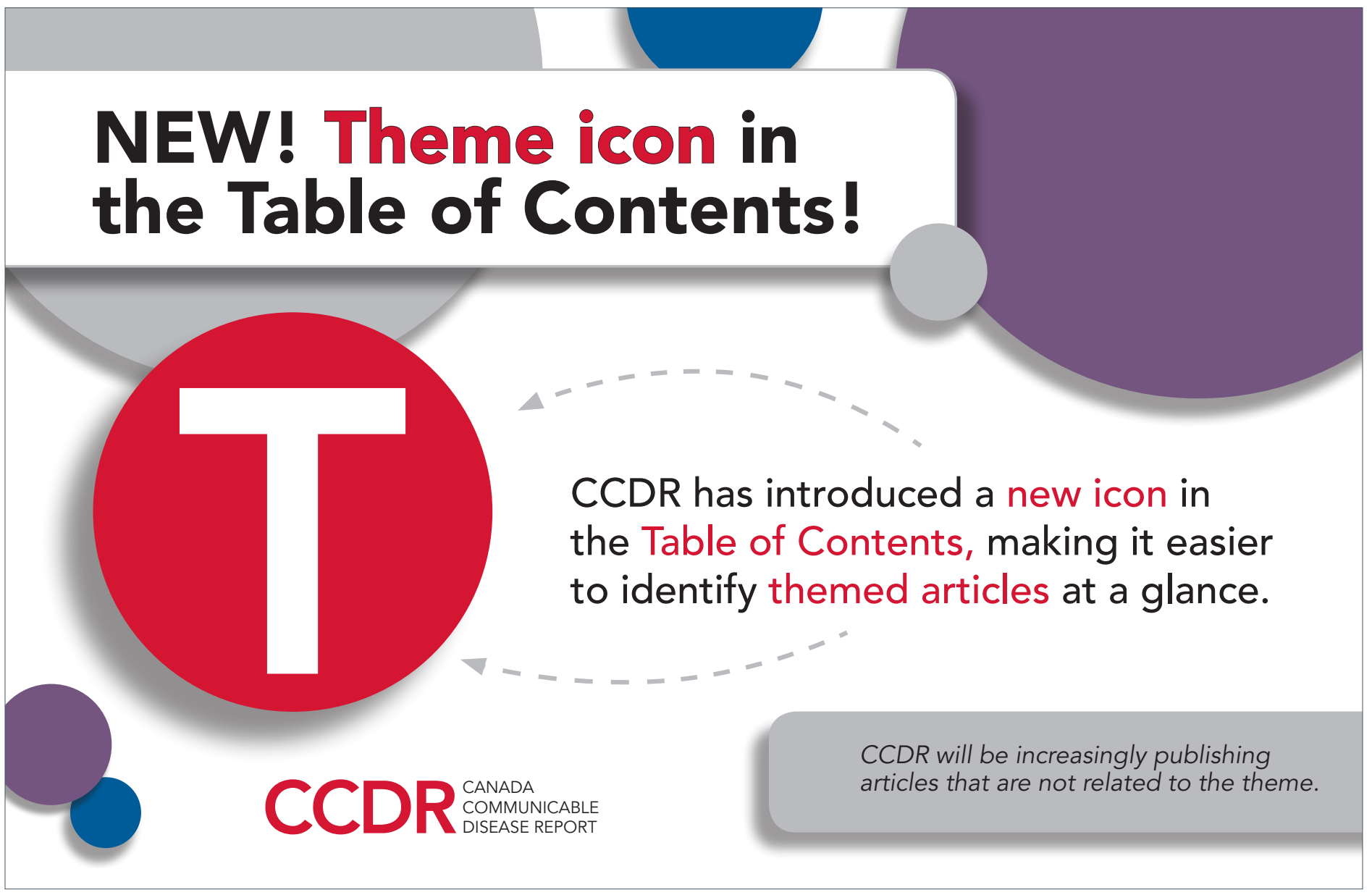

